\title{
The Predicative Paradigm
}

In this chapter, a variety of embedded, dependent, and mutually dependent clauses is discussed. In the grammatical literature, these clauses are treated separately, as distinct types of verbal complexes or subordinate structures. Nevertheless, these clauses have a common trait which justifies their analysis under a single heading: they all present the same set of verbal forms which function as second predicates in complex predications. I shall therefore apply the term the predicative paradigm to this set of forms. The following discussion will focus on the paradigmatic regularity, which can be shown to cross-cut diverse syntactic levels, and the functional oppositions marked by the predicative forms in each clause type.

\subsection{Preliminaries}

The term predicative has a long history in general linguistics. It is traditionally associated with a nominal—usually adjectival—form, which completes the content of the primary verbal (mostly copular) predicate. The predicative is sometimes distinguished from other related categories, such as the 'converb' and the 'co-predicative', both referring to an adverbial constituent (whether verb-derived or not) which 'expands' or 'restricts' the content expressed by the primary verb. ${ }^{1}$ However, the borderline between these categories is not clearly demarcated in every language. Moreover, there is no general consent as to their scope of application. ${ }^{2}$ I prefer, therefore, the term predicative for being general enough, i.e., for not being necessarily connected with a specific word-class (e.g., verb or noun), or a grammatical realization thereof (e.g., nonfinite or accusative). I use the term predicative to refer to the syntactic position assumed by a predicate whose function is to complete the content expressed by another predicate, so as to form a complex predication.

1 For a detailed discussion of these categories and some relevant literature, see Premper, "Zustandssätze", 304-321.

2 The term 'converb' would have been quite proper for the description of the predicative forms in Arabic, if not typically associated with non-finite verbs, see Haspelmath's definition of a converb as 'a nonfinite verb form whose main function is to mark adverbial subordination' (Converb, 3).

(C) MICHAL MARMORSTEIN, 2016 | DOI: 10.1163/9789004310483_009

This is an open access chapter distributed under the terms of the Creative Commons

Attribution-Noncommercial-Non-Derivative 3.o Unported (CC-BY-NC-ND) License 
Complex predications consist of (at least) two predicates, often referred to as 'primary' and 'secondary'. The primary predicate is the grammatical nucleus of the complex predication, whereas the secondary predicate is usually the semantically salient constituent. Rather than an hierarchy of predicates, it seems thus more correct to speak of integration or combination of predicates or clauses. Integration - as opposed to the traditional dichotomy of coordination and subordination-is regarded as a scalar phenomenon, accommodating various degrees and forms of predicate or clause-combining. ${ }^{3}$ The extent to which both predicates are integrated follows from the amount of grammatical and lexical material shared by them. Whether the construction presents a high degree of 'elaboration' or a high degree of 'compression', to use Lehmann's terms, ${ }^{4}$ integration entails that: (a) both predicates or clauses are not selfcontained syntactic units, and (b) they depict one common occasion.

In Classical Arabic the predicative paradigm consists of three forms: yaf'alu, the participle, and qadfa'ala. In this well-defined syntactic slot, one may speak of a basic aspectual meaning of the forms, yaf'alu marking a dynamic-progressive situation, the participle marking a static state, and qad fa'ala marking a state resulting from a previous process. As for their temporal value, the predicative forms are essentially co-temporal, indicating either simultaneity (total overlap) or coincidence (partial overlap) with the time frame established in the main clause:

TABLE 8.1 The predicative paradigm

\begin{tabular}{lll} 
Predicative form & Aspect & Temporal value \\
\hline yaf'alu & dynamic-progressive & simultaneous, coincidental (terminal) \\
${\text { fácil } V n / m a f^{\prime} u ̈ l V n}^{\prime}$ & static & simultaneous \\
qadfáala & resultative & coincidental (initial)
\end{tabular}

The triad of yaf'alu, the participle, and qad fa'ala constitutes the core of the predicative paradigm. The form facala seldom functions as a predicative. This may be explained by the fact that fáala is used to indicate self-contained events

3 See Van Valin, Syntactic Relations; Haiman and Thompson, "Subordination"; Halliday, Functional Grammar, $216 \mathrm{ff}$.; Lehmann, Clause Linkage; Matthiessen and Thompson, Discourse and Subordination; Raible, Junktion. In Arabic linguistics, see Isaksson, Circumstantial Qualifiers; most notably Waltisberg, Satzkomplex.

4 Lehmann, Clause Linkage, especially 216. 
(hence its use as the narrative form), not coinciding with other events. The same goes for sa-yaf'alu, which rarely participates in complex predications (see below 8.2.4). Quite often, when fa'ala and sa-yaf'alu are used, the predication involves a certain abstraction at the semantic level, thus calling for some extension of the notion of common occasion.

A wide definition of complex predications, as such realizing a certain degree of syntactic and semantic integration between (at least) two predicates, covers a large and quite heterogenic group of structures. These extend from simple morphological constituents-closely-integrated with their matrix clause-to textual units, where integration is rather loose. ${ }^{5}$ In the following sections, I start by discussing closely integrated complexes in which the predicative form is embedded. Then, one type of dependent clauses, the syndetic circumstantial clause, is discussed, and finally, mutually dependent, setting and presentative clauses are presented. The common denominator of all these constructions is the presence of the predicative paradigm.

\subsection{Verbal Complexes}

The term verbal complex covers various manifestations of [main verb + embedded verb]. These range from closely integrated structures, involving auxiliaries and modifying verbs, to lexically and grammatically looser ones, where the main verb retains its full semantics. ${ }^{6}$ The main verb is the grammatical nucleus of the complex in that it marks the syntactic status of the entire complex; the embedded verb is usually the lexical pivot of the complex. Nonetheless, it should be stressed that both verbs convey some amount of grammatical and lexical information: the main verb is never entirely depleted (even the auxiliary kāna may be said to convey the notion of 'being'), while the predicative form marks such categories as number, gender, diathesis, and aspect.

In both medieval and modern grammars of Classical Arabic, the structures which are here subsumed under the title of verbal complexes are treated as separate categories. Despite their formal identity, a distinction is drawn between structures initiated by the auxiliary kāna and the mental di-transitive verbs ('af'äl l-qulüb), in which the predicative is deemed as kernel, and structures

5 Most structures exhibit the iconic relation pointed out by Givón, Syntax, 2, 328, between semantic and syntactic integration: The greater is the semantic connectivity between two events the stronger will be the syntactic dependency between the clauses indicating them.

6 The same verb can have a double realization, either as a lexically 'full' verb (tämm) or as a lexically 'deficient' verb (nāqiș), which is thus followed by a predicative form. 
initiated by intransitive and mono-transitive verbs, in which the predicative is considered peripheral. The Arab grammarians designate the first type of predicative habar 'rheme' (paired-off with ism 'theme'), whereas the latter is termed hăal 'circumstantial' (defined in contrast to a proper maf'ūl 'object complement'). ${ }^{7}$ This distinction follows from a categorical semantic approach, classifying verbs into distinct 'families', and a strict formal view of the clause, dividing it into an essential part ('umda) and a redundant part ( fad la). However, the distinction between $h \bar{a} l$ and habar is not always kept, and the fact that the two terms are sometimes used interchangeably is in itself quite telling: it discloses the special identity of this syntactic constituent, which at the same time is both predicative (in its essence) and adverbial (in its position). ${ }^{8}$ From a diachronic point of view as well, adverbial-circumstantial and predicative clauses may be regarded as akin to each other: the latter, more inherently integrated with their matrix clause, reflect a further grammaticalization of the former. ${ }^{9}$

Verbal complexes present the same syntactic structure, whatever the lexical class of the main verb is: the predicative-a verb(-derived) form in adverbial position-is juxtaposed to the main verb; ${ }^{10}$ both verbs exhibit subject-identity (in that we include inalienable entities, see below [8.46]). The adverbial status of the predicative obtains a formal mark when the predicative is realized as a nominal (verb-derived) form, i.e., as the accusative participle. The finite forms yaf'alu and qad fa'ala occupy the same syntactic position as the participle and thus acquire — by virtue of their paradigmatic interrelation — an adverbial status.

The following discussion of verbal complexes is divided into five sections according to the class of the main verb. I will proceed from kāna-compounds, located on one end of the integration scale, toward less integrated complexes,

8 Levin, Kāna, 192-196, discusses the correspondence between the categories termed habar, $h \bar{a} l$, and maf'ūl țāni in Sībawayhi's Kitāb. It is worth quoting in this regard Ibn Ya īšš Šarh al-Mufașșal, 2, 7, who explicitly states that al-hâalu ziyādatun fi l-fäidati wa-l-habari 'The circumstantial expression is an addition to the informativity [of the clause] and to its predicate'. He explains that in a clause like marartu bi-l-farazdaqi qā̇iman 'I passed by al-Farazdaq [while] standing' the predication ('ihbār) of 'passing by' is added another predicate (habar 'ähar); the only difference is that the first is obligatory ('alä sabili lluzūmi), whereas the latter is additional and can thus be renounced (ziyādatan yağ $\bar{u} z u$ l-istigināu 'an-hā).

10 On the internal structure of compound verb forms and the adverbial status of the predicative complement see Goldenberg, Compound Verbs. 
initiated by modifying verbs, motion and state verbs, perception and permission verbs, and speech verbs. Complexes initiated by full action verbs (which present the same syntactic structure) are not dealt with. Nearly all the examples illustrate verbal complexes in main clauses (see but [8.16] and [8.18]). For kāna-compounds in dependent clauses, see chapter 7 above.

\subsection{1 kāna-compounds}

Compound kāna forms present the highest degree of integration within a verbal complex. The auxiliary verb kanna expresses either a temporal or a modal meaning (see above 5.2.3). In this section, however, I will only discuss compounds initiated by the anterior kāna. The predicative form indicates the content of the verbal situation as well as its internal unfolding. The opposition between the predicative forms operates therefore at the lexical as well as the grammatical levels.

The compound form kāna yaf'alu was thoroughly studied by Nebes, who applied a semantological method of categorization to his Classical Arabic material. ${ }^{11}$ The form kāna yaf'alu, according to Nebes, is an imperfect whose marked time reference is past. This meaning of kāna yaf'alu stands in opposition to the marked perfectivity of facala, on the one hand, and the unmarked time reference of $y a f^{\prime} a l u$, on the other. ${ }^{12}$

The present discussion in not concerned with the general function of kāna yaf'alu. Rather, the opposition between yaf'alu and the other verbal forms which co-occur with kāna is in focus. As mentioned, this opposition resides in two domains: (a) the lexical domain, to which the issues of lexical compatibility and the valence of the verb-phrase belong, and (b) the grammatical domain, in which the aspect marked by the verbal form comes into play.

The verbal form yaf'alu is the least lexeme-sensitive of all verbal forms: it may convey all types of verbal situations, both static and dynamic, telic and atelic, and be realized in both intransitive (active and passive) and transitive verb-phrases. Intransitive and transitive are used here in a strict syntactic sense, to refer to the grammatical relation between a verbal situation and its accusative complement(s). ${ }^{13}$ As for its grammatical aspect, yaf'alu depicts an unbounded situation: either one that continues throughout the period of time indicated by kāna, or one that constantly repeats itself. The repetition is frequentative in nature, i.e., it is not a mere iteration of the verbal situation, but

\footnotetext{
11 Nebes, Kāna Yaf'alu, especially chapter 2, in which his analytical method is presented.

12 Ibid., especially chapter 7 .

13 As a semantic concept, transitivity is obviously multi-faceted and scalar, cf. Hopper and Thompson, Transitivity.
} 
a regular and predictable recurring which is valid through the entire period of time indicated by kāna. ${ }^{14}$ In the following, the various manifestations of kāna yaf'alu will be illustrated and explained.

With both stative and dynamic lexemes, kāna yaf'alu occurs in transitive verb-phrases. Transitivity may code a different semantic relation in each case:

(8.1) wa-kāna rasūlu llāhi yuḥibbu l-fa’la wa-yakrahu l-țìrata

The Messenger of God used to love the good omen and hate the evil omen. (Maj̇̄̄zī, 218)

(8.2) 'ayyu-hā l-maliku kunna qawman 'ahla ğāhiliyyatin na'budu l-'așnāma wa-na'kulu l-maytata wa-na'tī l-fawāḥiša wa-naqța'u l-'arhāma wanusìu l-ğiwāra

O king! We were people of the Ğăhiliyya, worshiping the idols, eating the carrion, committing abominations, violating the rules of consanguinity, and harming those who sought our protection. (Sira 1, 219)

(8.3) wa-kāna mra’an tanașșara fì l-ḡāhiliyyati wa-kāna yaktubu l-kitāba l'ibrāniyya fa-yaktubu min-a l-'inǧlli bi-l-ibrāniyyati mā šăà llāhu 'an yaktuba

And he was a man [who] became Christian in the Ğăhiliyya. He used to write in the Hebrew script and would write in Hebrew whatever God wished him to write from the Gospel. (Șahịh, 5)

Also in intransitive verb-phrases kāna yaf'alu is used. Example [8.4] below exhibits the passive form of 'arafa 'to know':

(8.4) fa-'ahrağa qawsa-hū wa-ğu'bata-hū wa-sayfa-hū wa-kāna yu'rafu bi-lšă̌ă'ati

And he took out his bow and his quiver and sword; and he was known for [his] bravery. (Mag் $\bar{a} z \bar{\imath}, 223$ )

Within kāna-compounds, certain lexemes are not encountered with the participle but only with yaf'alu. These pertain to various classes of verbs, including mental states, ${ }^{15}$ perception, or action:

14 For a discussion of the semantic nature of frequentative repetition, see below 11.3.

15 The verb yurìdu is another prominent case where yaf'alu is preferred to the participle, see also Waltisberg, Satzkomplex, 293. 
(8.5) wa-kuntu 'arğū 'an 'arudda-hū 'alà qurayšin fa-'ăhuda l-miata nāqatin And I was hoping to bring him back to Qurayš and to get [as a reward] the one hundred she-camels. (Sira 1, 331)

(8.6) fa-kuntu 'arā min-a l-nāsi wa-l-hayli mā là 'așifu min-a l-katrati And I saw people and horses which I cannot describe due to their great numbers. (Mag் $\bar{a} z \bar{\imath}, 408)$

(8.7) wa-kāna 'abū'aḥmada rağulan darìra l-bașariwa-kāna yațūfu makkata

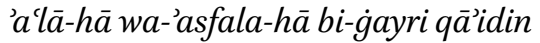

'Abū 'Ahmad was a blind man and he used to walk around Mecca, [from] its highest [to] its lowest parts, without anyone to lead [him the way]. (Sir $a 1,316)$

The compound kānayaf'alu often co-occurs with adverbs and adverbial clauses which specify the frequentative nature of the verbal situation:

(8.8) wa-kāna 'id ā rakiba yab'ațu 'ilay-himā bi-ba'îrayni yarkabāni ma'a-hü And whenever he rode, he used to send to both of them camels so that they would ride with him. (Riwāyāt $\left.1,5^{8}\right)$

(8.9) wa-kāna 'abū bakrin kațīran mā yasta'dinu rasūla llāhi fì l-hiğrati 'Abū Bakr kept asking the Messenger of God for permission to [set out] on the Hiğra. (Sira 1, 323)

In some cases, kānayaf'alu co-occurs with the modifiers qad and la-qad, which precede the compound form as a rule. The modifier qad expresses both anteriority (already indicated by kāna) and completion:

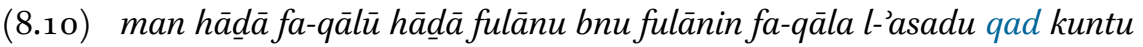
'a'rifu' abā-hu

Who is this? They said: 'This is so-and-so, son of so-and-so.' So the lion said: 'I had known his father.' (Kalïla wa-Dimna, 70)

In [8.10] the 'knowing' of the father, who is already deceased by the time the clause is uttered, is marked as 'cut-off' by qad. The modifier la-qad, unlike the plain qad, embodies an explicit mark of asseveration. Thus, in [8.11] the speaker asserts the unusual sight he has seen by means of la-qad: 
(8.11) la-qad kunnā narā riǧālan bịdan 'alā ḩaylin bulqin mā kunnā narā-hum qablu wa-là ba'du

Indeed, we saw white men on piebald horses. We never saw them before or after. (Maḡāzi, 409)

Following kāna, the predicative yaf'alu is always negated with $l \bar{a}$ :

(8.12) fa-harağnā nas'alu 'an rasüli llāhi wa-kunnā lā na'rifu-hū lam nara-hū qabla d̄àlika

We went out to ask the Messenger of God, and we did not know him, nor had we seen him before that. (Sira 1, 294)

The compound form kāna fäilan/maf'ülan shows a clear contrast to kāna yaf'alu, at both the lexical and the grammatical levels. The predicative participle is found almost exclusively in intransitive configurations. It serves to indicate a static situation which is viewed in its entirety, i.e., which does not break down into internal phases or recurrent instances.

The predicative participle is used with stative lexemes:

(8.13) wa-kullu-hum kāna lè muḥibban wa-ilay-ya mä̉ilan wa-lì muṭīan And everyone loved me and was favorably inclined to me and was obedient to me. (Riwāāāt 1,35)

Notice that muhibban is connected with its object by means of the preposition $l-16$ whereas yuhibbu in [8.1] has a direct object. Derived from verbs of mental state and disposition, the adjectival patterns facil, facil, and faclän often serve as predicative forms side by side with the participle:

(8.14) wa-našảa l-nağāāìyu ma'a 'ammi-hī wa-kāna labïban ḥāziman min-a l-riğāli

The Negus grew up with his uncle, and he was wise and resolute from among the men. (Sira 1, 222)

16 The Arab grammarians consider this $l$ - as al-läm li-taqwìyat al-ämil 'the lām which strengthens the regent', cf. Wright, Grammar, 2, $61 \mathrm{ff}$. Being a nominal form, the participle has less 'power' to govern an object complement; the lām thus serves as an explicit exponent of this grammatical relation. 
The participle is very common with verbs of state and motion. With motion verbs, the participle indicates the situation of being in a move, rather than actual kinesis or progression:

(8.15) wa-kāna 'adiyyu bnu zaydin wāqifan bayna yaday-hi 'Adī b. Zayd was standing in front of him. (Riwāyāt 2, 184)

(8.16) hattā 'idāa kunnā bi-l-mușallā rāğíína min badrin baraka 'alay-nā Until [the time] when we were near al-Muṣallā, coming back from Badr, it (i.e. the camel) fell on its knees (lit. 'kneeled down to us'). (Maj̇āzī, 25)

Besides indicating the mental state of a subject, the participle is also found with stative lexemes depicing a physical state:

(8.17) wa-kāna dāri'an wa-'alay-hi miğfarun lā rafrafa la-hū fa-kānat ḥanğaratu-hū bädiyatan

And he was wearing armor and a helmet with no visor, so his neck was exposed (lit. 'visible'). (Maḡāzī, 227)

The participle rarely occurs with transitive lexemes. When it does, it is often realized in the passive form, so that the verb-phrase is intransitive:

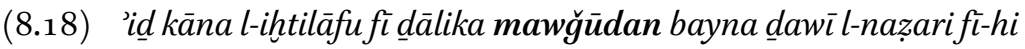
As the controversy about that [matter] exists between those holding a view about that. (Ta'rih 1,86$)$

The participle may also be realized in the active form. However, in these cases transitivity is not exercised, since the verb occurs without an explicit object complement:

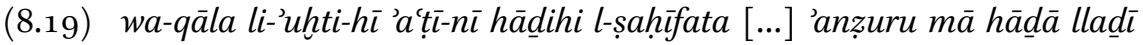
ğăa bi-hì muhammadun wa-kāna 'umaru kätiban

And he said to his sister: 'Give me this leaf [of book ...] so that I may take a look at that which Muhammad has brought,' for 'Umar was literate (lit. 'writer'). (Sira 1, 226)

Comparing the participle in [8.19] and yaf'alu in [8.3], we observe two points of contrast: (a) the participle kătiban has no object complement, and (b) rather than indicating recurring instances of writing like yaktubu, it expresses a state 
so stable that has reached the status of a skill. This stands to reason, as the participle is an adjectival form which inherently indicates an attributive relation. Whether the attribute is accidental (temporary) or inherent is not specified by the participial form, but only by the context. ${ }^{17}$

The compound kāna fä 'ilan/maf'ülan is occasionally preceded by the modifiers qad and la-qad. As elsewhere, qad imparts both the meanings of anteriority and completion, thus it sets limits to the static situation indicated by kāna fäilan/maf'ülan; la-qad stresses the veracity of the verbal situation:

(8.20) qad kuntu 'anā ğâhilan mițla-ka hattā waffaqa-nì llāhu 'ilā mā huwa 'aršadu

I used to be ignorant like you until God made me successful in achieving the right way. (Buhalä, 40)

(8.21) la-qad kāna 'ilay-nā muhssinan wa-la-nā mukarriman Indeed, he was good to us and honoring us. (Kalïla wa-Dimna, 103)

Within kāna-compounds, the predicative participle is negated as a rule by gayr: ${ }^{18}$

(8.22) wa-kānat-i l-am'äu muttașilatan ġayra mutabāyanatin

The intestines were intertwined [and] not separated from each other. (Buhalä, 99)

The compound form kāna qad fa'ala or qad kāna fa'ala can be analyzed in two ways: as the modified form qad fa'ala expanded by kāna, or as the compound form kāna fáala modified by qad. Examples of both orders are found in the corpus, although kāna qad fáala is by far more common:

(8.23) wa-kānū qad 'uțū basțatan fíl-ḩalqi

They were given a large stature. (Ta'rihh 1, 167)

17 Cf. Reckendorf, Zum Gebrauch des Partizips, 256. There are languages in which the distinction between an accidental and an inherent attribute is marked on the (inflected) adjectival form, see Goldenberg, Predicative Adjectives.

18 I have encountered one case in which the predicative participle was negated by $l \bar{a}$ in a conditional clause: fa-'in kunta lā 'ākilan šay'an sakattu 'anā wasakatta 'anta (Buhalä', 47) - And if you were not eating anything, I would have been silent and you would have been silent.' This example is unusual in two points: the participle is negated by $l \bar{a}$ and realized in a transitive verb-phrase. 


\section{(8.24) wa-qad kāna 'uṭiya fatā’a l-sinni}

He was given youth (lit. 'the youth of age'). (Riwāyāt 1, 19)

The compound kāna qad fa'ala embodies the meanings of anteriority and completion. Anteriority is doubly marked by both the modifier and the auxiliary. Similarly to kāna fáala (to be discussed below), kāna qad fáala is mostly used as a background form in the narrative. However, kāna qad fa'ala is more frequent and has a wider distribution than kāna fáala. It is found with nearly all classes of verbal lexemes; the only class of verbs which does not occur with kāna qad fa'ala is that of state verbs such as 'aqāma 'to dwell'. This may be explained by the fact that kāna qad fa' ala — due to the effect of qad-indicates a temporally framed situation which is incompatible with stative background descriptions. Indeed, we often encounter kāna qad fáala in contexts where temporality, or to be more precise, the successive order of the events, is salient to the narrative:

(8.25) fa-lammā rağa'a ba'da ḥinin țalaba ḥadìda-hū wa-kāna l-rağulu qad $\boldsymbol{b} \bar{a} \boldsymbol{a} a-h \bar{u}$

And after a while, when he came back, he asked for his iron, [but] the man had already sold it. (Kalìla wa-Dimna, 119)

(8.26) wa-kāna 'abū 'àmirin-il-fāsiqu qad haarağa fì hamsīna rağulan min'awsi llāhi ḥattā qadima bi-him makkata hịna qadima l-nabiyyu l-madīnata 'Abū 'Āmir, the sinner, had already gone out with fifty men from 'Aws Allāh until he arrived with them in Mecca, at the time when the Prophet arrived in Medina. (Maḡā $z \bar{l}, 205$ )

(8.27) fa-'in kāna d̄ālika ka-d̄ālika fa-qad kāna l-mā̉u wa-l-rịhu huliqā qabla l-'arši

If this is so, then the water and the wind were created before the throne. (Ta'īh 1, 37)

The compound form käna fáala is less frequently used than kāna qad fáala. It gains preference in cases where the lexical input is incompatible with the meaning of bounding marked by qad, or when the relative order of the events is not considered as important as the assertion of their actual occurrence. Example [8.28], for instance, presents a case where käna fáala occurs with the state verb makata 'to stay': 
(8.28) kāna nūḥun makata fíqawmi-hì alfa sanatin 'illā ḩamsīna āman yad'ūhum 'ilä llāhi

Noah had stayed among his people for $95^{\circ}$ years (lit. 'thousand years minus fifty years'), calling upon them to [worship] God. (Ta'rihh 1, 186)

In narratives, kāna fa'ala is used when the temporal sequence is not deemed as important as the assertion of the actual occurrence of the events. Notice the difference between [8.25] and [8.29], extracted from the same story: in the first case, the temporal sequence is crucial to the point of the narrative (the man claims back his iron after the iron has already been sold); in the latter case, the events themselves (that are reported in direct speech) are given the most focus:

(8.29) kuntu waḍatu hadìda-ka fì nähiyatin min-a l-bayti fa-'akala-hü l-ğurd̄ānu (Kalīla wa-Dimna, 119)

I had placed your iron at a corner of the house and the rats ate it.

Although the temporal sequence is not in focus, kāna fa'ala may co-occur with temporal adverbs:

(8.30) wa-kāna ğabalun harağa laylan min mawdii in kāna fi-hi

Ğabal had gone out at night from the place where he had been. (Buhalä, 65)

In [8.30] the adverb laylan 'at night' indicates the temporal setting of the situation. However, this setting is not presented as relative to some other point. The compound kāna fa'ala also occurs with the focus particle 'innamā, which stresses the veracity of the situation expressed in the clause. In this case, too, it is not the relative position of the event within the narrative sequence that is being asserted, but the fact that it has actually taken place:

(8.31) 'innamā kāna qatala l-qātilu min-humā 'ahā-hu 'anna llāha 'azza wağalla 'amara-humā bi-taqrïbi qurbānin

The fact of the matter is that one of them killed his brother because God ordered them to offer a sacrifice. (Ta'rih 1, 142)

As it does not carry a specific marking of temporal framing, kāna fáala is also compatible with an adverb such as rubbam $\bar{a}$, which indicates an unbounded iteration: 
(8.32) wa-kānū rubba-mā hasșsu-hu fa-waḍa'ū bayna yaday-hi l-durrāğata lsaminata

They often endowed him with special honor and put in front of him a plump francolin. (Buhalä', 85)

The predicative qad facala is generally incompatible with negation. The predicative fa'ala is also not negated. Instead, lam yaf'al is used:

\section{(8.33) kānayahrusu rasūla llāhi lam yufāriq-hu}

He used to guard the Messenger of God; he would not leave him. (Maj̄̄āi, 217)

\subsubsection{Modifying Verbs}

Modifying verbs, 'ahawāt kāna 'kāna's sisters' in the Arabic grammatical tradition, serve to describe a certain phase or aspect of the verbal situation, which is expressed by the predicative form. In Classical Arabic, modifying verbs comprise several lexical classes; ${ }^{19}$ however, the main semantic distinction can be drawn between two groups of verbs: those which indicate the initial phase of the verbal situation and those indicating its continuation or duration. There are no modifying verbs referring to the terminal phase of the verbal situation or to its accomplishment, hence this group of verbs is incompatible with the resultative meaning of qad facala.

The predicative form $y a f^{\prime} a l u$ is compatible with both groups of modifying verbs. The most common representative of the first is ğa'ala 'to start'. ${ }^{20}$ The verbal complex ğa'ala yaf'alu is found with all classes of verbs, in affirmative and negative forms:

(8.34) fa-ğáala yamšı̀ wa-yaq'udu wa-yanzuru 'ilà l-țarīqi hattā rufía la-hū dimnatu muqbilan

And he started to walk and sit and look at the road until Dimna, [while] approaching, came into his sight. (Kalìla wa-Dimna, 75)

19 Modifying verbs, the same as kāna, can also be used as full verbs. Cf. Waltisberg, Satzkomplex, 198-199, for some ambiguous examples, where the verbal form may be interpreted either as a modifying or a full verb.

20 Waltisberg, Satzkomplex, 348, reports that verbs indicating ingressivity formed $72 \%$ of the modifying verbs attested in his corpus; the verb ğa'ala had by far the greatest number of tokens. 
(8.35) fa-ğa'alū ya ̣ribūna-hum ḥattā nuqiḍat șufüfu-hum And they started to hit them until their lines were destroyed. (Mag் $\bar{a} z \bar{l}$, 226)

(8.36) fa-ğa'alū lā yatrabūna la-humā wa-lā yư̌ğabūna bi-himā kamā kānū yatrabūna

And they stopped (lit. 'started not') being moved and delighted by them the way they used to be. (Riwāyant 1, 57)

With cognitive verbs which are, by their nature, static, ğa'ala indicates the entrance into a state or a disposition, thus the meaning of becoming ('starting to be'):

(8.37) wa-ğa'ala ’abū ğahlin yusarru bi-mā șana'a l-mušrikūna bi-'utbata And 'Abū Ğahl became delighted by what the polytheists did with

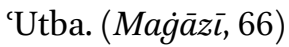

Besides ğa'ala, there are other verbs which indicate inchoative meaning. These originate from diverse lexical classes, e.g.: 'așbaha 'to be [in] day time', 'ahada 'to take', indafa'a 'to rush off'. The modifying verb șāra, illustrated in [8.38], also functions as a motion verb indicating the arrival at a certain place or destination (e.g. șāra 'ilā fulānin 'He came to such a one'):

(8.38) fa-iḍa șirtu ka-d̄ālika fa-qad ḍahaba kasb-ī min māli ġayr-ī wa-șāra gayr-ì yaksibu min-nī

If I become like that, my earnings from someone else's money will disappear and someone else will start earning from me. (Buhalä’ 93)

To the same group of inchoative verbs also belong verbs indicating imminence or intention. These verbs do not refer to the actual outset of the verbal situation but to the phase immediately preceding it, either in the physical or in the mental world of the agent: ${ }^{21}$

(8.39) fa-lammā ntahā 'ilā l-nahri lam yağid 'alay-hi qanțaratan li-yaqța'a-hū wa-l-di'bu kāda yudriku-hü

21 In the Arabic grammatical tradition, 'af'āl al-šurū' 'the verbs of beginning' and 'af'āl almuquaraba 'the verbs of approximation' are lumped together, cf. Wright, Grammar, 2, 106109 . 
And when he got to the river he did not find a bridge to cross it over, while the wolf was about to reach him. (Kalïla wa-Dimna, 63)

The predicative $y a f^{\prime} a l u$ often co-occurs with the second group of modifying verbs, indicating the continuation or duration of the verbal situation. Among these verbs, lam yazal 'to not cease' is by far the most frequently encountered. Notice in [8.41] the opposition between the predicative participle and yaf'alu, the first indicates a static situation while the latter indicates a dynamic one:22

(8.40) wa-naḥnu lam nazal naḍribu-hū bi-suyūfi-nā ma'a l-awsi fì ḥarbi-him kulli-hā

And we continued to fight him with our swords, together with 'Aws, throughout their war. (Majīa $z \bar{\imath}, 369)$

(8.41) wa-qüla 'anna-hū lam yazal muqìman bi-makkata yaḥuğğu wa-ya'tamiru

It was reported that he continued to stay in Mecca, performing the pilgrimages of the Hajj and the 'Umra. (Ta'rih 1,164$)$

The predicative participle is seldom found with the first group of modifying verbs indicating an inchoative meaning. This may be explained by the nonphasal nature of the participle, which rules out the reference to its internal phase. However, with stative lexemes, the participle may co-occur with modifying verbs conveying the meaning of becoming, i.e., the entrance into a new state. In such cases, the verbal situation is not broken down into its internal phases but the entire situation ('non-being $\mathrm{x}^{\prime}$ ) is transformed to another ('being $\left.\mathrm{x}^{\prime}\right)$ :

(8.42) wa-qad wallāhi yā rasūla llāhi 'aṣbaḥtu muštāqan 'ilā murāfaqati-hī fì l-ğannati

By God, O Messenger of God, I have come to yearn to accompany him in Heaven. (Ma $\dot{a} \bar{a} z \bar{\imath}, 213)$

The participle is quite common with the second group of modifying verbs indicating the continuation or duration of the verbal situation. As with kāna, the predicative participle mostly occurs in intransitive verb-phrases:

22 Ta'īh 3, 1150, provides a parallel example, in which yaf'alu specifies, by negation, the dynamic aspects of 'standing still': fa-mā ziltu wāqifan mā 'ataqaddamu 'amām-ī wa-lā 'arği $u$ wară'-ī 'And I kept standing, I did not proceed forward or returned back.' 
(8.43) wa-lam 'azal li-d̄âlika l-sammi min lisāni-ka hăàifan mušfiqan 'an ya'urra-n̄̄ bi-šay'in kārihan li-qurbi-ka d̄ākiran li-maw'izati l-'uqalā'ifi ğtinābi muqārabati 'ahli l-fuğūri

And because of your poisonous tongue, I kept being afraid and worried that I would be ashamed of something, [and I kept] hating your closeness [while] remembering the lesson of the wise men: to avoid being close to immoral men. (Kalïla wa-Dimna, 118)

Besides typical modifying verbs such as lam yazal or mā dāma, there are other verbs which serve to indicate continuation or duration. These are often motion and state verbs, such as madā 'to pass' and labita 'to abide', which in some contexts undergo semantic bleaching:

(8.44) fa-labița l-'awsu wa-l-hazrağu mutahạäribìna 'išrīna sanatan fí 'amri sumayrin

'Aws and Hazrağ kept fighting for twenty years because of the matter of Sumayr. (Riwāyāt 2, 19)

As mentioned above, modifying verbs expressing either inchoative or durative meaning are incompatible with qad fa'ala. Also the simple fa'ala is rarely found with modifying verbs; the few existing examples stem mostly from poetry. ${ }^{23}$ In my corpus, I have encountered one example in which the form 'arāda 'he wanted' co-occurred with the modifying verb 'as ā 'it might be'. The compatibility of 'arāda and 'asā may be explained by the fact that, as opposed to qad fa'ala, fa'ala does not indicate the complete and concrete realization of the verbal situation:

\section{(8.45) fa-'asā-hu 'arāda l-tafộla fì l-qismati}

Perhaps he wanted [to be given] preference in the allotment [of the gifts]? (Buhalä', 91)

\subsubsection{Motion and State Verbs}

Verbs expressing a movement towards a destination or a certain position or location in space are very common in complex predications. Such verbs indicate the outset or setting of the verbal situation which is specified by the following predicative form. With this group of verbs we find the predicative triad yaf'alu, fácilan/maf'ülan, and qad fa'ala, marking the opposition between a

23 Cf. Reckendorf, Arabische Syntax, 297, for poetry quotes such as 'așbahat 'ad dalatnī. 
progressive, a static, and a resultative aspect, respectively. As both the main verb and predicative verb refer to the same situation and are co-temporal, fa'ala-being neither simultaneous nor coincidental-is excluded from the predicative paradigm.

In both traditional and modern grammatical literature, verbal complexes initiated by motion and state verbs provide the most typical example of circumstantial constructions. While the Arab grammarians were mostly concerned with the grammatical properties of the hăl 'circumstantial expression', and the syntactic relation with its (pro)nominal antecedent, i.e. $\underline{d} \bar{u}$ al-ḥal 'the circumstantial expression's referee', modern studies of circumstantial clauses focus on the semantics of the main verb and its effect on the interpretation of the predicative form. The following discussion is concerned with the semantic compatibility between the main verb and the predicative verb, as well as the functional opposition between the predicative forms.

In the Arabic grammatical tradition, the predicative form yaf'alu is considered to have two manifestations: (a) as hăal muqārin 'simultaneous circumstantial', or as (b) hạlmuqaddar 'intended circumstantial.' ${ }^{24}$ Modern grammars maintain the same distinction between yaf'alu forms which are 'simultaneous with or following the action expressed by the governing verb. ${ }^{25}$ In his short article, Abboud diverts attention from yaf'alu to the semantics of the main verb: since $y$ af'alu co-occurs with 'event-completion' verbs, it may refer either to the event or to its 'eventual completion'. According to Abboud, such an explanation 'obviates the need for a hăl muqaddar'. ${ }^{26}$ A somewhat different view is presented in Waltisberg's work on circumstantial clauses. Although he, too, maintains that the semantics of the main verb affects the interpretation of yaf'alu, Waltisberg suggests a neat separation between a 'modal' (simultaneous) and a 'final' (posterior) function of yaf'alu, which are then paired off with syndetic circumstantial clauses and final clauses, respectively. ${ }^{27}$

A detailed examination of all the possible combinations shows that the temporal value of yaf'alu is not solely determined by the content of the main verb, nor by that of the predicative verb, but by the interaction of both. We observe a general rule: if (at least) one of the verbal lexemes is potentially unbounded (a-telic), then yaf'alu is interpreted as simultaneous (totally overlapping); if neither is unbounded, then yaf'alu is interpreted as coincidental (partially

24 Cf. Wright, Grammar, 2, 19-20.

25 Fischer, Classical Arabic Grammar, 220.

26 Abboud, Hāl Construction, 195.

27 See Waltisberg, Satzkomplex, $§ 5.2$ and $§ 5.6$; Cf. Marmorstein, Review on Waltisberg, 381382 . 
overlapping), i.e., the situation expressed by yaf'alu proceeds from the one expressed by the main verb. The coincidental relation should not be analyzed as simple succession, since both the main verb and yaf'alu refer to the same situation, the first depicting its outset or setting, the latter its destination.

The rule outlined above is demonstrated in the following set of examples, where the main verb indicates: (a) movement towards a destination, i.e., motion and goal; (b) movement in space with no goal; or (c) static position in space. In [8.46]-[8.47] the main verb belongs to the first group of motion verbs while the predicative verb indicates an unbounded situation; yaf'alu is thus interpreted as simultaneous:

(8.46) fa-rağa'a bi-hā rasūlu llāhi yarğufu fu'ādu-hū

And the Messenger of God returned with them (i.e. the verses) his heart shivering. (Șahīh, 5)

(8.47) fa-labisa dir'a-hū wa-'ahada sayfa-hū fa-harağa ya'dū

He wore his armor, took his sword and went out running. (Majīa zì, 370)

In [8.48] the main verb belongs to the first group of motion verbs while the predicative verb indicates a bounded situation; yaf'alu is thus interpreted as coincidental:

\section{(8.48) fa-harağù yaṭlubūna-humā fi kulliwağhin}

They went out looking for both of them in all directions. (Riwāyāt 2, 24)

In [8.49] the main verb belongs to the second group of motion verbs; yaf'alu is thus interpreted as simultaneous:

(8.49) wa-marrū yaḍibūna bi-l-dufüfi wa-yazmirūna bi-l-mazāmìri They marched striking tambourines and playing the pipes. ${ }^{28}$ (Maj $\bar{a} z \bar{\imath}$, 375)

In [8.50]-[8.51], where the main verb belongs to the third group of state verbs, yaf'alu, whether unbounded or bounded, is interpreted as simultaneous:

28 The verb marra can be interpreted as either bounded ('to pass by') or unbounded ('to march'). In the latter case, no limitation or destination of the movement is indicated, as in [8.49]. 
(8.50) fa-bāta yabkì

He spent the night crying. (Riwāyāt 2, 32)

(8.51) fa-bātū yaṭlubūna-hū ḥattā ya’isū min-hu

They spent the night looking for him until they gave up all hope of [finding] him. (Riwāyāt 2, 178)

Not only with verbs of (vectorial) motion, but also with verbs of caused motion, yaf'alu indicates the goal of the event launched by the main verb:

(8.52) fa-'arsala 'ilay-hi yad' 'u-hu

And he sent to him [a messenger] inviting him [to come]. (Riwāyāt 2, 29)

In these cases, too, yaf'alu is not strictly successive, nor does it indicate finality; rather, it indicates the terminal stage of the verbal situation. That the two notions, i.e., final and terminal, are not simply overlapping can be demonstrated, inter alia, by the fact that proper final clauses, such that are introduced by an explicit operator (e.g. li- 'for'), are external to the verbal situation and hence can be negated, whereas the terminal yaf'alu-being an internal and inseparable part of the verbal situation - is never negated.

While coincidental or terminal yaf'alu forms cannot be negated, yaf'alu indicating simultaneity does exhibit negation with $l \bar{a}$. Quite often, $l \bar{a}$ yaf'alu paraphrases the content expressed by the preceding (affirmative) predicative form:

(8.53) wa-bātat șāhilatan haylu-hum là tahda'u

Their horses stayed up the night neighing; they would not calm down. (Maj̄äzì, 217)

(8.54) wabaqütu mabhūtan lā 'astațīu l-kalāma wa-lā l-ğawāba wa-lā l-harakata li-mā hālața qalb-ī

I remained speechless; I could not talk nor respond or move for what had befallen me. (Riwāààt 1, 46)

The predicative participle depicts a static situation. It may indicate: (a) the outcome of a previous process in the passive form; (b) the persistence in a certain state with dynamic lexemes; or (c) the endurance of a state with stative lexemes. These three options are illustrated in the examples below. Notice that in [8.56] the participle, as elsewhere (see [8.17] above), is used to describe 
physical appearance, dressing, and specifically, the girding of a sword (other parallel examples are Riwāyāt 2, 185: mutaqallidan; Sìra 1, 225: mutawǎšsihan); Example [8.57] demonstrates the functional opposition between the participle and yaf'alu with regard to transitivity: the first is used in intransitive verbphrases whereas the latter takes an object complement:

(8.55) fa-makata mumallakan 'alay-hā 'ašhuran

He remained its king (lit. 'enthroned') for several months. (Riwāyāt 2, 184)

(8.56) fa-'aqbala muṣlitan sayfa-hū fìnafarin min-a l-yahūdi He approached unsheathing his sword amid a group of Jews. (Maj̇̄zi, 372)

(8.57) fa-ḩarağnā huäifìna nahăfu l-rașada

We set out afraid; we were fearing an ambush. (Mag் $\bar{a} z \bar{\imath}, 28)$

The last example illustrates a general principle of complex predications. We may refer to it as the principle of increased specificity: each predicative is added to the previous one, thereby depicting the given situation in greater detail. The increased specificity is obtained by the accumulation of predicates, and not by their internal order. Consider, for instance, [8.58]-[8.59] in which rakiba 'to ride' functions either as the main (specified) verb or as the predicative (specifying) form:

(8.58) lam 'arkab hațatan dِāhiban wa-là rāğían

I did not ride a single step either going or coming. (Mag் $\bar{a} z \bar{\imath}, 26)$

(8.59) 'aqbaltu rākiban 'alā ḥimārin 'atānin

I came close, riding on a she-ass. (Șahịh, 31)

Quite often, the lexemes of both the main verb and the predicative form pertain to the same class of motion verbs. According to Waltisberg, in such cases the participle serves to mark 'situation-identity' between both verbal forms. ${ }^{29}$ It appears, however, that the notion of situation-identity fails to capture the specifying function of the participle and its semantic contribution to the verbal complex. To be sure, there are cases where the content of both verbs is very

29 Waltisberg, Satzkomplex, 286-291. 
similar. However, even in these, the predicative is not simply tautological, but serves to elaborate the content of the main verb, often by indicating the point of departure or the direction of the motion:

(8.6o) wa-'aqbala 'abū ğubaylata sā̉iran min-a l-šāmi And 'Abū Ğubayla came proceeding from al-Šām. (Riwāyāt 2, 11)

\section{(8.61) hattā qumtu fì qiblati-hī mustaqbila-hū}

Until I stood in his direction of praying facing him. (Sira 1, 228)

Unlike yaf'alu, the participle is rarely interpreted as indicating the terminal stage or destination of the verbal situation. Example [8.62] is one case that may be interpreted as such:

\section{(8.62) ğìtu-ka ‘äidan bi-ka}

I came to you asking for your protection. (Riwāàa $t$ 1, 55)

In other cases where the main verb indicates vectorial motion, what one usually finds is the participle indicating an appointment or assignment, rather than the destination or goal. As an adjectival form, the participle is most suited to the expression of such attributes, whether these have a temporary or a permanent validity. Example [8.63] provides a good illustration to the distinction between the participle, indicating an appointment, i.e., an (assigned) attribute, and yaf'alu, which breaks down this attribute into its actual instances. The Qur'ānic quote in [8.64], which has a parallel in the Sira, is yet another case where the participle, like non-derived adjectives, is used to indicate an appointment ('being sent as') rather than a goal ('being sent to');

(8.63) fa-ba'ața llāhu 'iblīsa qāḍiyan yaqựi bayna-hum

God sent 'Iblīs as a judge to judge among them. (Ta'rīh 1,85$)$

(8.64) fa-ba'ața llāhu l-nabiyyīna mubašširìna wa-mundirìna / wa-lākinna llāha ba'ata-nī bašìran wa-nadīran

God sent the prophets as bringers of glad tidings and warners. (Q 2:213; Ta'rīh 1, 184) / But God sent me as a bringer of glad tidings and a warner. (Sira 1, 189)

As already mentioned above, a predicative fa'ala is incompatible with motion verbs, due to its self-contained temporal framing (this is not to be confused with the notion of boundedness: facala, with stative lexemes, may well indi- 
cate unbounded persisting situations). The modified qad fa'ala, on the other hand, does co-occur with motion verbs, indicating a process whose result is coincidental with the situation expressed by the main verb. As opposed to the coincidental yaf'alu, the tangent point of qad fa'ala and the main verb is not the terminal stage of the latter but its initial one:

(8.65) fa-ğăàa 'a rābiyyun qad 'aqbala min tihàmata

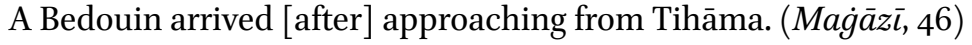

(8.66) wa-’aqbala l-mušrikūna qad șaffü șufüfa-hum

The polytheists approached [being] already arranged in lines. (Maj̇ $z \bar{a} \bar{l}$, 220)

\subsubsection{Perception and Permission Verbs}

Perception verbs and verbs indicating permission form a sub-group of complement-taking verbs in Classical Arabic. Both these classes of verbs head raising constructions. The term 'raising' refers to the syntactic fusion of two clauses, a complement-taking verb and its propositional complement, whereby the subject of the second clause is fronted to the object position of the first. The raised element is in fact shared by both clauses, and thus cannot by analyzed as an exclusive member of either. ${ }^{30}$

The mechanism of raising allows for two interpretations of perception verbs: either as indicators of concrete perception of an object and its condition (e.g., 'I saw him doing'), or as indicators of notional perception of a whole situation or fact (e.g., 'I saw that he was doing'). The latter use may trigger a further shift or abstraction of the meaning of the verb, from physical perception to mental comprehension (e.g., 'I realized that he was doing'). ${ }^{31}$

30 Discussing such examples as 'I found her gone', Jespersen, Philosophy, 122, suggests regarding the entire combination ('nexus') her gone as the object of the main verb. According to Givón, Syntax, 2, 272, such cases exhibit the process of raising, whereby an argument of the subordinate clause is converted to an argument of the main clause. By contrast, Waltisberg, Satzkomplex, 322-323, views the raised element as still belonging to the embedded clause. As a matter of fact, this question cannot be decided, for the raised element is formally marked (through its case and agreement) as relating to both clauses at the same time.

31 According to Arabic grammatical tradition, when ra'ā and wağada are not intended in their physical denotation (i.e., in the sense of ru'yat al-'ayn 'the seeing of the eye' or wiğdān al-dālla 'the finding of the lost beast'), but rather in their mental denotation, their second object is indispensable to the clause, serving as the predicate of the first object, see Sībawayhi, Kitāb, 1, 13 . 
The distinction between the patterns of concrete and notional perception is not only semantic, but it also has syntactic correlates: (a) complement clauses introduced by the operator 'anna are not free variants of raising constructions, but mostly interchange with the pattern of notional perception; ${ }^{32}$ and (b) the paradigm of predicative forms which is compatible with the expression of notional perception is wider and also includes verbs not indicating cotemporality with the main verb. Thus, while the pattern of concrete perception involves only the predicative triad, yaf'alu, qad fa'ala, and the participle, the pattern of notional perception also includes fa'ala and sa-yaf'alu, both referring to events which are not envisaged as co-occurring with the situation of perception.

The predicative form yaf'alu occurs with both patterns of concrete and notional perception. With the first pattern, yaf'alu depicts an ongoing situation, simultaneous with the moment of seeing, hearing, or finding:

\section{(8.67) fa-ra'ā-nì 'atawaḍ̂’u min kūzin hazafin}

He saw me performing the ablution using a pottery jug. (Buhalä, 37)

(8.68) 'a-mā wallāhi la-samitu muhammadan yaqūlu

Verily, by God, I heard Muḥammad saying. (Majḡazzi, 35)

(8.69) wa-'tabir 'ayḍan d̄âlika bi-l-milhi llad̄i yūḍa'u tahta l-misrağati wa-lnuhālati llatī tūdáu hunāka li-taswiyati-hā wa-tașwībi-hā kayfa tağiduhumā yan'așirāni duhnan

Consider that too, along with the salt that is put under the lamp, and the bran that is put there to level it and tilt it, how much oil you will find them (i.e., the salt and bran) to exude. (Buhalä', 41)

In the negative form as well, la $y$ yaf'alu functions as predicative in raising constructions. Example [8.70] is ambiguous in that the syntactic relation between the indefinite object qawman and the following là yurídūna can be analyzed as either predicative or attributive (see above 6.1.3):

(8.70) wa-lākinnì wallāhi ra'aytu qawman là yurìdūna 'an ya'ūbù 'ilā 'ahlì-him But, by God, I saw people not willing to return to their families. ( $M a-$ $\dot{g} \bar{a} z \bar{l}, 62)$ 
The predicative yaf'alu is also compatible with $r a^{3} \bar{a}$, when this indicatesrather than concrete ocular perception - the seeing of a certain scene in a dream or the envisioning of a scene:

(8.71) 'innī qad ra'aytu ru'yan [...] wa-'arā bn-ì yațlubu-nì țalaban hațītan I dreamt (lit. 'I saw a dream') [...] and I see my son looking for me anxiously. (Sira 1, 254)

With the second pattern of notional perception or comprehension, yaf'alu expresses a prediction, a situation that is not concomitant but posterior to that indicated by the main verb. As the moment of comprehension does not coincide with the comprehended fact, the posterior sa-yaf'alu may also be used:

(8.72) fa-tarā muhammadan yaḥșiru-nā sanatan

Do you think that Muhammad will besiege us for a year? (Mag $\left.\bar{a} z \bar{\imath},{ }_{3} 68\right)$

(8.73) wa-'ammā talabu bn-ì 'iyyā-ya tumma ḥabsu-hū 'ann-ī fa-innī 'arā-hu sa-yağhadu 'an yușība-hū mā 'așāba-nì

And as for my son's looking for me and being withheld from me, I see it [as if] he will strive so that what happened to me will happen to him [too]. (Sira 1, 254)

As with verbs of motion and caused motion, when yaf'alu co-occurs with permission verbs it may be coincidental, referring to the terminal stage of the complex situation:

(8.74) fa-qad 'amara-nā 'an lā nada'a-ka tastaqirru 'alà l-'ardi

He has instructed us to not let you stick to the ground. (Riwāyāt 1, 248)

The predicative participle is compatible with the expression of concrete as well as notional perception. In both cases it depicts a static situation, one that exists or persists at the moment of perception:

(8.75) țumma ğàat-i mra’atu l-hağğāmi ba'da sāatin li-musāmarati șadìqatihā mra’ati l-iskājifa-wağadat-hā marbūṭatan

Then the wife of the cupper came after one hour to have an evening chat with her friend, the wife of the shoemaker, and she found her tied up. (Kalïla wa-Dimna, 79) 


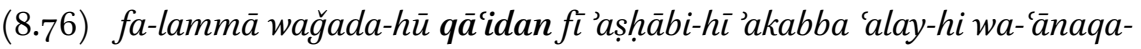
$h \bar{u}$

When he found him sitting among his friends, he bent down over him and embraced him. (Buhalä, 43)

(8.77) fa-qultu yā rasūla llāhi mā la-ka 'an fulānin fa-wallāhi 'innī la-'arā-hu mu'minan

So I said: 'O Messenger of God, what do you have [in mind] about soand-so, for by God, I think he is a believer.' (Șahịh, 15)

With verbs indicating permission, the predicative participle also depicts a static situation. Notice that in [8.78] the participle, as elsewhere, is intransitive, whereas the following yaf'alu has an object complement:

(8.78) fa-'ahbara-nā 'anna muḥammadan kāna 'araḍa li-'iri-nā fì bad'ati-nā wa-'anna-hū taraka-hū muqìman yantaziru rağ'ata-nā

And he informed us that Muhammad was observing our caravan since we started our [journey], and that he had left him to stay [there] and watch for our return. (Mag் $\bar{a} z \bar{\imath}, 28)$

The predicative form qad facala, in both patterns of concrete and notional perception, is used to indicate a process whose resultant state coincides with the time of perception itself:

(8.79) 'asma'u l-șawta qad-i rtafa'a fì 'a là qawrā

I hear the voice already risen at the top of Qawrā. (Riwāyāt 2, 47)

(8.80) 'innī'arā qurayšan qad 'azma'at 'alā l-ḩurūği

Indeed, I think that Qurayš have already decided to go out. (Majīaz $\bar{\imath}$, 36)

As is usually the case, qad fa'ala is preferred to fa'ala when the chronological order of the events is deemed salient to the narrative. Thus in [8.81], the fact that 'Adī was already dead when the messenger found him, and not just the mere fact of his death, has great bearing on the later development of the narrative:

(8.81) 'innì wağadtu 'adiyyan qad mäta qabla 'an 'adhula 'alay-hi I had found 'Adī already dead before I entered upon him. (Riwāyāt 2, 191) 
In some cases, the perceived situation consists of a number of scenes, either overlapping or following each other in time. Example [8.82] is a good illustration of the predicative triad. We observe that the order of the forms-first the participle, then yaf'alu, and qad fa'ala - is a fixed one, regardless of the nature of the matrix clause. This order may be viewed as iconic, reflecting the decreasing degree of integration of the predicative form with the main verb: ${ }^{33}$

(8.82) wa-la-ka-'annī ’anzuru 'ilay-kum zāininina yataḍāga șibyānu-kum qad taraktum dūra-kum hulüfan wa-’amwāla-kum

It is as if I look at you departing, your children crying out, [after] you have left your homes and possessions neglected. (Mag் $\bar{a} z \bar{\imath}, 365)$

In my corpus, a predicative fa'ala was not found in raising constructions very often. Unlike the temporally bounded, coincidental qad fa'ala, fa'ala refers to a self-contained period of time. With concrete perception, fa'ala is found with lexemes indicating an enduring state. Notice in [8.83] the indefinite time frame indicated by the adverb zamānan 'for a while':

(8.83) 'innī qad ra'aytu l-malika 'aqāma bi-makāni-hì hādāa zamānan lā yabrahu min-hu

Indeed I have seen [that] the king remained in this place of his for a while, not moving from it. (Kalìla wa-Dimna, 73)

The predicative fa'ala is more likely to occur when perception is not intended in its physical sense, but in its mental sense. Thus, fa'ala is used in visions and dreams, or in the expression of realizations and conclusions:

(8.84) ra'aytu rākiban 'aqbala 'alā ba'îri-hī [...] fa-'arā l-nāsa ğtama'ū 'ilay-hi I saw [in a dream] a rider [that] approached on his camel [...] and I saw [that] the people gathered to him. (Mag் $\bar{a} z \bar{l}, 29)$

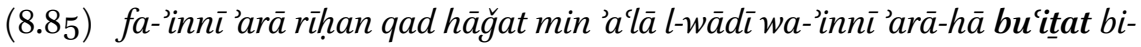
nașri-ka

I see a wind has risen from above the valley and I think it has been sent to help you. (Maj̄̄āi, 29) 
As is the case elsewhere, the predicative fa'ala is not encountered in the negative form; instead, lam yaf'al is used:

(8.86) inhaḍ-i l-sā'ata 'ilā l-faḍli bni yahyā fa-'inna-ka taǧidu-hū lam ya’dan li'ahadin ba'du

Get up [and go] now to al-Fạ̣l b. Yahyā; you will find him not allowing anyone [in] yet. (Riwāyāt 1, 30)

\subsubsection{Speech Verbs}

Another defined class of verbs which initiate verbal complexes are speech verbs. The predicative forms which co-occur with speech verbs are yaf'alu and the participle. These forms increase the specificity of the verbal situation by referring either to the content expressed or to the vocal quality of speech itself. Notice that [8.88] exhibits an unusual case where the participle is followed by an object complement:

(8.87) qāla l-’a šā yamdahu l-samaw’ala

Al-’A‘̌sā said praising al-Samaw’al. (Riwāyāt 2, 27)

(8.88) qāla l-walìdu rāfían șawta-hū

Al-Walīd said raising his voice. (Buxalä, 65)

\subsection{Circumstantial Clauses}

Not only in verbal complexes, i.e., in embedded clauses, but also at higher syntactic levels, the predicative paradigm is found. In this section I will discuss one type of dependent clause, the circumstantial clause, in which the predicative triad is used. The aspectual oppositions between the forms are the same as those described above: yaf'alu indicates an ongoing situation or process, the participle indicates a static state, and qad fa'ala indicates a result.

The category of al-ǧumla al-hâliyya 'the circumstantial clause' was described by the Arab grammarians as a complex ('periphrastic') manifestation of the $h \bar{a} l$ category. However, modern research has demonstrated that the asyndetic hăl constituent and the syndetic ğumla hâliyya do not interchange freely with each other. ${ }^{34}$ In fact, there are a number of formal and functional distinctions between them:

34 Cf. Premper, "Zustandssätze"; Isaksson et al., Circumstantial Qualifiers; Waltisberg, Satzkomplex. 
(a) The subject of the syndetic circumstantial clause is not necessarily coreferential with the subject of the main clause, thus both clauses do not necessarily refer to the same verbal event. It should be noted, however, that the subject of the circumstantial clause is not entirely new, but can be retrieved from the previous context. ${ }^{35}$

(b) The syndetic circumstantial clause is not lexeme-sensitive: it does not cooccur with specific classes of verbs in the matrix clause.

(c) Syndetic circumstantial clauses are backgrounded whereas their asyndetic counterparts are foregrounded. The latter distinction is often correlated with the temporal relation marked by the syndetic and asyndetic clause, to wit, simultaneity vs. sequentiality (or chaining). ${ }^{36}$ Although generally correct, this correlation is too sweeping. As was already discussed, the predicative forms refer to situations which overlap with the situation indicated by the main verb, or which precede or proceed from that situation.

The formal and functional distinctions outlined above reflect different degrees of integration of asyndetic and syndetic circumstantial clauses and their matrix clause. The asyndetic predicative forms, occupying the position of an adverbial (accusative) complement, show a higher degree of integration than syndetic circumstantial clauses, connected to their matrix clause as self-standing clause units (we recall that the participle in syndetic circumstantial clauses takes the nominative case!). Also from a functional point of view, asyndetic predicative forms serve to single out a certain aspect, feature, or stage of the complex situation. Syndetic circumstantial clauses, on the other hand, are comments elaborating on a certain entity, depicting in greater detail the situation indicated in the main clause, or describing the setting in which the latter takes place.

Except for some minor cases in which $f a$ - is used, the circumstantial clause is connected as a rule with $w a-{ }^{37}$ The connective $w a$ - is a general connective particle: it simply indicates the adjoining of two or more elements or clauses. The particular semantic relation between the adjoined clauses, whether it

35 It is rather unusual that the subject of the circumstantial clause is newly introduced into the text. As the following example shows, the subject may be indefinite, though still strongly associated with other topics and hence presupposed (like inalienabilia): kuntu 'inda šayhin min 'ahli marwa wa-șabiyyun la-hū șaj̇irun yal'abu bayna yaday-hi (Buhală' 38)-'I was at [a place of] a sheikh from the people of Marw, and a young boy of his was playing in front of him'.

36 Cf. Premper, "Zustandssätze", 275.

37 For circumstantial clauses introduced by fa-, see Nebes, Satzschema. 
be chronological, causal, contrastive, or other, is not indicated by $w a$ - but determined by the given context. ${ }^{38}$

$w \bar{a} w$ al-hâl 'the circumstantial $w a-$ ' may introduce either a nominal or a verbal clause (see above 4.5). When the predicate is yaf'alu or the participle, the nominal clause pattern is mandatory; with qad facala, the pattern of the verbal clause is preferred, although there are a few examples where the subject is fronted. In the following, I will illustrate and discuss circumstantial clauses with each of the verbal forms.

Circumstantial clauses whose verbal predicate is yaf'alu may refer to a situation concomitant with the one indicated in the matrix clause. The concomitant relation is sometimes interpreted as contrastive, especially when the subject of the circumstantial clause is not only different, but in fact confronted to the subject of the main clause:

(8.89) fa-ğa'altu 'amš̀̃ ruwaydan wa-rasūlu llāhi qã̉imun yușallì yaqra’u lqur'āna

I started to walk slowly while the Messenger of God was standing, praying, [and] reciting the Qur'ān. (Sïra 1, 228)

(8.9o) fa-dahala 'alay-hi rağulun kāna la-hū ğāran wa-kāna lī șadìqan fa-lam ya'riḍ 'alay-hi l-ta'āma wa-nahnu na'kulu

When in came a man, a neighbor of his and a friend of mine, and he did not offer him food, though we were eating. $\left(\right.$ Buhala $\left.{ }^{3}, 38\right)$

Like the asyndetic yaf'alu, the circumstantial yaf'alu-being co-referential with the subject of the main verb-may refer to the same verbal event as the latter. Thus, in [8.91]-[8.93], the same verb qāla is followed each time by a circumstantial clause, specifying either the manner of speech, its location, or the content expressed:

(8.91) fa-lammā qāla surāqatu mā qāla wa-huwa yanțiqu bi-lisāni 'iblīsa šağu'a l-qawmu

And when Surāqa said what he said, and he was speaking with the tongue of 'Iblīs, the people were encouraged. (Majā $z \bar{\imath}, 39)$

$38 \quad$ For a different view of syndetic circumstantial clauses, as such indicating a 'catalogue' of semantic relations, see Waltisberg, Satzkomplex, 358. König, Converb Constructions, provides a general account of the controversy over the polysemous or vague nature of adverbial verb forms. 
(8.92) sami'tu 'alìyan yaqūlu wa-huwa yahțubu bi-l-kūfati

I heard 'Alī saying while he was delivering a sermon in Kufa. (Mag்äzi, 57)

(8.93) [...] qāla wa-huwa yuḥaddițu 'an fatrati l-wahyi

He said, while delivering a hadit on the period of pause in revelation. (Șaḥịh 1, 6)

In circumstantial clauses yaf'alu is negated by lā. Quite often, lā yaf'alu occurs with verbs of knowledge, depicting a situation where one subject is ignorant about the activity of the other:

(8.94) fa-marrat-i l-hayyatu 'alā l-hazanati wa-hum là ya'lamūna The snake passed by the keepers [and entered] while they did not know. (Ta'rih 1,104$)$

Circumstantial clauses whose predicate is the participle are either co-referential with the situation depicted by the main verb, or refer to a concomitant situation. We observe that the participle in [8.95] follows a non-derived adjectival form which indicates the mental state of the subject (see [8.14] above). In [8.96], the participle refers to the physical appearance of the subject, specifically to his girding for battle (another example is Mag $\bar{a} \bar{a} z \bar{\imath}$ 1, 39: wa-huwa mutawaššịun bi-sayfi-hī; see also [8.17] and [8.56] above):

(8.95) fa-ğàà-nī wa-huwa hazizinun munkasirun He came to me sad and [heart] broken. (Buhalä', 9o)

(8.96) wa-'ahada l-nabiyyu l-qawsa wa-'ahada qanātan bi-yadi-hī [...] wa-lmuslimūna mutalabbisūna l-silāha

The Prophet took the bow and he took the spear in his hand [...] while the Muslims were putting on their weapons. (Maj̇̄ zī, 215)

The same as the asyndetic participle, the circumstantial participle occurs as a rule in intransitive verb-phrases, either with intransitive lexemes or, with transitive lexemes, in the passive form:

(8.97) laqiya-hū safĭhun min sufahā̉i qurayšin wa-huwa 'ämidun 'ilā l-ka'bati One of the Qurayš fools came across him while he was heading towards the Ka'ba. (Sira 1, 246) 
(8.98) li-’anna-hū lā šay’a yatawahhamu-hū mutawahhimun fì qawli qā̉ili dâlika 'illā wa-huwa mawğūdun fí qawli qã̀ilin

Because there is nothing which one may presume [to be implied] in this statement without existing in a statement such as ... (Tarinh 1,58$)$

On rare occasions the participle takes an object complement. We observe, however, that the object in such cases is not a prototypical one, i.e., an individualized affected entity, but in fact, forms a collocation with the verbal form:

(8.99) wa-kayfa yastațīu dِālika wa-huwa 'àkilun 'ušban

How is he able to do that while being a grass-eater? (Kalïla wa-Dimna, 92)

Circumstantial clauses whose predicate is qad fa'ala exhibit mainly the pattern of the verbal clause, although one may encounter a few cases in which the subject is fronted:

(8.100) wa-rağa'a l-nağǎšiyyu wa-qad 'ahlaka llāhu 'aduwwa-hū

The Negus came back [after] God had already destroyed his enemy. (Sira 1, 221)

(8.101) wa-harağa l-ḩabaru 'ilā l-nāsi wa-riğălu bañ̄ l-mușțaliqi qad-i qtusimū wa-mulikū

The news went out to the people, while the men of the Banū Muștaliq had already been divided [among their captors] and become [their]

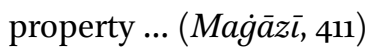

A plausible explanation to the different clausal pattern of wa-qad facala visà-vis wa-huwa yaf'alu/wa-huwa fä'ilun may be that the latter nominal patterns are indeed plot-external descriptions, sometimes even generic or encyclopedic comments, centered on a certain entity, while wa-qad fa'ala, though deviating from the main facala-plotline and depicting an anterior event, is not purely descriptive, but rather incorporated in the stream of events (see also below 10.3.2).

Circumstantial clauses sometimes present the inna la-clausal pattern. The operator 'inna introduces the entire clause whereas the modifier la-precedes the predicate. When the predicate is verbal, la- may be prefixed to either yaf'alu or the participle. The structure wa-inna la- has an emphasizing function: it indicates that the content expressed in the clause stands against a certain expectation, explicit or implicit in the surrounding context, and that it is there- 
fore remarkable. There is an important functional distinction between ordinary circumstantial clauses and wa-inna la-clauses: unlike the first, wa-inna la-clauses are not merely descriptive or orientational (if at all), but they present the personal evaluation of the narrator regarding the narrated situation. Consider, for instance, the examples below:

(8.102) wa-la-qad rảaytu-hū yanzilu 'alay-hi l-wahyu fì l-yawmi l-šadìdi l-bardi fa-yufșimu 'an-hu wa-inna ğabina-hü la-yatafașșadu 'araqan And I saw him [when] the revelation came upon him, on a very cold day; then it departed from him, while his forehead was dripping with sweat. (Sahịh, 6)

(8.103) fa-la-qad luddat maymūnatu wa-'inna-hā la-șāìmatun

And Maymūna was given the medicine while she was fasting. (Sìra 2, 1007)

In [8.102], 'A'iša says that it was an extremely cold day when the revelation came upon the Prophet, but nevertheless she saw that he was sweating. In [8.103], Maymūna is reported to be given medicine, despite the fact that she was fasting.

Being unusual in the nominal clause pattern, qad facala is also not found in the 'inna la- pattern. Nevertheless, qad fa'ala is compatible with the emphasizing la-which precedes the modified form. The same as wa-inna-hü layaf'alu/wa-'inna-hü la-fácilun, also wa-la-qad fa'ala has an evaluative function: it imparts the impression of the narrator regarding the related event:

(8.104) la-qad ḥaddata-nī 'abdu llāhi bni 'abbāsin 'anna 'ādama nazala ḥina nazala bi-l-hindi wa-la-qad hạğğa min-hā 'arbaīna hiğğatan 'alā riğlay-hi ${ }^{39}$

'Abdallāh b. 'Abbās told me that when Adam came down it was in India; from there he had performed the pilgrimage to Mecca on foot forty times. (Ta'ihh 1, 124)

39 Interestingly, wa-la-qad hağğa does not refer to an anterior event relative to the preceding nazala. It may be that la-qad fa'ala, as opposed to qad fa'ala, serves mainly an expressive goal and is not used for the purpose of grounding. This suggestion awaits further research. 


\subsection{Mutually Dependent Clauses}

Mutually dependent constructions are exocentric, that is, neither their first nor their second part may be said to function as the main constituent or nucleus to which the other is subordinate. As already discussed above (6.1.2), mutual dependency is marked as distinct from other types of interdependency by inverting the usual order of the conjoined dependent clause, from subsequent position to initial. The global meaning of a mutually dependent construction is gathered from the contents of both its parts, so that neither one can be omitted without giving up much of the sense of the entire construction.

Conditional sentences are perhaps the best known example of mutually dependent constructions. The conditional meaning is obtained by the juxtaposition of a protasis and an apodosis. ${ }^{40}$ Conditional clauses may be introduced by the same conjunction as modifying adverbial clauses, e.g.: 'in 'if', 'id $\underline{d} \bar{a}$ 'when/if'. However, the relative position of the clause determines its interpretation. When the clause takes the initial position it is a conditional, when it is postposed it is an adverbial expansion of the main clause. ${ }^{41}$ The seemingly inverted order of the conditional construction marks the relation of mutual dependency, whereby both clauses have an equal syntactic status. ${ }^{42}$ Not only the syntagmatic order, but also the paradigmatic constitution of the verbal forms is different in conditionals and in modifying adverbial clauses. Prototypical conditional sentences present a limited range of possibilities, the verbal form in the protasis-fa'ala or yaf'al-triggers off the verbal form in the apodosis-fa'ala or yaf'al, and both forms assume a hypothetical meaning. ${ }^{43}$

40 Cohen, Conditionals, 15, views the syntactic relationship between both parts of the conditional construction as mutual dependency. As far as their semantic interrelation is concerned, 'ordinary conditionals' are defined by him as 'structures containing two domains of events or state of affairs' of which 'neither domain can be confirmed or denied at the time of the utterance, and the likelihood of one domain (the apodosis) to take place depends directly on the realization of the other domain (the protasis)'.

That the protasis and apodosis cannot be inverted while maintaining their function was already observed by the Arab grammarians. The Arabic terminology also reflects the distinction between a proper conditional, termed šart, and a postposed modifying conditional, termed zarf; cf. Peled, Conditional Structures, 139-140.

42 A conditional clause is not just less integrated with its matrix clause, compared to postposed dependent clauses (Waltisberg, Satzkomplex, 75-77); rather, it exhibits a different kind of interdependency, a mutual dependency.

43 Besides the prototypical construction there are other types of conditional sentences in which the apodosis is not selected by the protasis but, following the conjunction $f a$-, is free 
By contrast, modifying adverbial clauses are free to follow a wide variety of clause patterns, ${ }^{44}$ and the temporal or modal meaning of their verb, as is generally the case in dependent clauses, is relative to the point of reference of the main clause.

Apart from conditional sentences, there are other types of mutually dependent constructions. The present discussion focuses on those in which the predicative paradigm is employed. These constructions can be divided into two interrelated kinds: (a) setting clauses and (b) presentative clauses. Although the predicative paradigm is common to all of them, there is an important difference between verbal complexes and circumstantial clauses, on the one hand, and setting and presentative clauses, on the other. The former operate at the syntactic level of the complex-clause, and thus may be found in any type of discourse, e.g., dialogues, narratives, expositions, etc.; the latter operate at the text level and can only be found in narratives. They are, in fact, marked patterns of narration (for a detailed discussion, see below 10.4).

\subsubsection{Setting Clauses}

Setting clauses are introduced by the operator ( $f a-)$ baynā/baynamā 'while'. They take the first position in the complex construction (like conditional clauses), followed by a presentative clause. Clauses headed by baynā/baynamā exhibit the pattern of the nominal clause, where the nominal theme precedes an adverbial (prepositional) or a verbal predicate. In cases where the predicate is verbal, it is realized as either yaf'alu or the participle, always in the affirmative. Here, as well, we observe the opposition between the dynamicprogressive-transitive yaf'alu and the static-intransitive participle:

\section{(8.105) baynā 'anā 'amšı 'id sami'tu șawtan min-a l-samāi}

As I was walking, I suddenly heard a voice from heaven. (Șaḥih, 6)

(8.106) fa-baynamā humā wāqifāni bayna yaday-hi 'id saqața țāirāni 'alāl-sūri And while they were standing in front of him, suddenly two birds landed on the wall. (Riwāyāt 2, 180)

The modified form qad fa'ala, incompatible with the durative (unbounded) meaning of baynā/baynamā, is not attested in this clause type. However, qad

to comprise verbal and nominal patterns other than fa'ala or yaf'al; cf. Peled's category of 'modally split conditional sentences' (Conditional Structures, chapter 4). 
fa'ala may be incorporated into the setting in the form of a circumstantial clause. Notice that in [8.107] the subject of the circumstantial is fronted, so as to match the order of the baynā/baynamā clause:

\section{(8.107) fa-baynā ’anā fìmağlis-īwa-l-hadamu qad haffü bīwa-ğawāriy-yayata- raddadna bayna yaday-ya 'idā 'anā bi-šayhin} And while I was in my living room, the servants had already surrounded me and my maids were coming and going in front of me, all of a sudden there was an old man with me. (Riwāaya 1 1,45)

Setting clauses may also take the form of the 'inna la-pattern. The same as in baynā/baynamā-clauses, yaf'alu and the participle function as verbal predicates. The distinction between setting clauses introduced by baynāalbaynamā and those introduced by 'inna is not a syntactic one:45 both types of clauses exhibit a mutually dependent construction with the same verbal paradigm. Rather, the distinction resides in the domain of expressivity. Setting clauses introduced by inna signal the presence and stance of an internally involved, 'homodiegetic' narrator, telling the story from his own first-hand experience: ${ }^{46}$

45 I hold a different view than Nebes, Inzidenzschema, who draws a syntactic distinction between a setting clause introduced by baynā/baynamā and one introduced by 'inna. The first is labeled 'the dependent clause-main clause construction', whereas the latter is labeled 'the "emphatic" main clause-main clause construction'. According to Nebes, the past time reference of yaf'alu (the imperfect) in the baynā/baynamā-clause is obtained due to its being dependent upon and concomitant with fa'ala (the perfect) in the following superordinate clause. In 'inna-clauses, by contrast, yaf'alu does not assume its past meaning relative to fa'ala, but is interpreted as 'historic present': its temporal value is endowed by the speaker/narrator, who envisions past events as if currently unfolding in front of his eyes. In my view, both clauses exhibit the same syntagmatic relations and paradigmatic structure: $y a f^{\prime} a l u$ and the participle in both cases mark the same aspectual distinctions, while the temporal frame of reference is established by the eventive-narrative fa' ala. Moreover, the general qualification of 'inna as 'emphatic' can be further specified. To be sure, 'inna does not indicate a contrastive focus; it does not assert the content of the clause against the explicit or implicit preceding context. On the contrary, 'inna (like baynā /baynamā) presents cataphoric background: it frames the narrative scene in which the dramatic development is about to take place.

46 For the notion of 'homodiegetic', see Genette, Narrative Discourse, 245. In my corpus I could find only one example in which a setting clause introduced by 'inna did not stem from a first-person narrative. In this example the predicate is not verbal but a prepositional phrase, thus the following presentative is introduced by 'idā: fa-inna 'abda l-hakami yawman la-fí l-masğidi l-harāmi 'ị̂a fatan dāhilun (Riwāyāt 1, 64)—'One day while 'Abd al-Hakam was in the holy mosque, there came in a young man'. 
(8.108) fa-wallāhi 'innī la-'amšì naḥwa-hū [...] 'ị harağa naḥwa bābi banī sah$\min$

By God, I was walking toward him [...] when suddenly he went out toward the gate of Banū Sahm. (Mag் $\bar{a} z \bar{\imath}, 31)$

(8.109) fa-wallāhi 'innī la-qā 'idun fì 'ahl-ì 'ị nazartu 'ilā za ìnatin By God, I was sitting among my people when suddenly I noticed a woman in a camel-borne sedan. (Sïra, 2, 948)

\subsubsection{Presentative Clauses}

Presentative clauses take the second position in the complex construction. Presentative clauses which involve the predicative paradigm are introduced by the particle 'id $\bar{a}$ and exhibit the pattern [nominal-phrase + predicative form] ${ }^{47}$ The predicative paradigm comprises the triad of $y a f^{\prime} a l u$, the participle, and qad fáala. Interestingly, the participle in 'id $\bar{a}$-clauses-rather than taking the accusative case (as in verbal complexes) - assumes, as a rule, the nominative case: 48

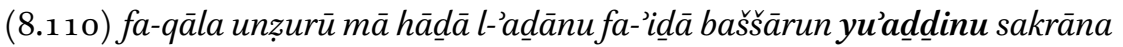
And he said: 'Look what is this call!' And there was Baššār calling for prayer while drunk. (Riwāayàt 1, 261)

47 The nominal presentee after 'i $\underline{d} \bar{a}$ may be definite or indefinite. It either takes the nominative case or is realized as the genitive complement of the preposition bi- 'with'. However, when followed by a predicative form, the nominal presentee is nearly always attested in the nominative.

48 In my corpus, as well as in the major grammars of Classical Arabic, there are no examples of ' $i \underline{d} \bar{a}$-presentatives in which the participle is attested in the accusative case. On the other hand, there are quite a few examples of presentatives introduced by $h \bar{a} \underline{d} \bar{a}$ in direct speech, in which the participle takes the accusative, e.g.: fa-qāla yā rasūla llāhi hāâā 'umaru bnu l-hațtāb mutawaššihan l-sayfa (Sīra 1, 227) —'And he said: O Messenger of God, [out] there is 'Umar b. al-Hațtāb girding the sword'. This double manifestation of the participle is explained by Bloch, Presentative Structures, as a semantogrammatical development of presentatives in Arabic, from 'amplified' constructions, in which the participle (or some other form) is adverbial (i.e. accusative), to 'proclitic' constructions, in which it is predicative (nominative). In a synchronic view, however, the fact that a fluctuation between both manifestations exists is by itself instructive: it reflects the adverbial-yetkernel status of this 'amplifying' term, which, unlike other adverbials (e.g., temporal or locative), forms part of the predicative core of the clause, see above 8.2. 
(8.111) fa-ǧìtu 'ilā ìbrāhìma l-mawșiliyyi fa-'idà l-bābu maftūḥun wa-l-dihlīzu qad kunisa wa-l-bawwābu qāidun

I came to 'Ibrāhīm al-Mawșilī, and behold, the door was opened, the hall was already swept, and the door-keeper was sitting. (Riwāyāt 1, 28)

(8.112) fa-fataha-hā la-hū fa-'idāa fi-hā șūratu 'àdama wa-durriyyati-hī kulli-him fa-'idà kullu rağulin maktūbun 'inda-hū 'ağalu-hū wa-'id̄a 'àdamu qad kutiba la-hü 'umru'alfi sanatin

He opened it (i.e. His hand) for him, and behold, in it there was the picture of Adam and all his progeny, and there was the [life] term of each man written down with Him, and there was Adam, a term of

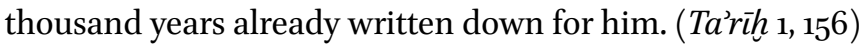

\subsection{Summary}

In this chapter, I have discussed a paradigm of verbal forms which function as predicatives in complex predications. This paradigm consists of yaf'alu, the participle, and qad fa'ala, marking an ongoing situation, a state, and an outcome, respectively. All three forms are co-temporal, either simultaneous (totally overlapping) or coincidental (partially overlapping) with the time frame established in the main clause. The predicative paradigm cross-cuts different syntactic levels: it is used in verbal complexes and circumstantial clauses at the (complex-)clause level, and in mutually dependent constructions at the text level, as summarized in table 8.2 below:

TABLE 8.2 The predicative paradigm across the board

\begin{tabular}{lll}
\hline & The predicative triad & Other verbal forms \\
\hline verbal complexes & $\begin{array}{l}\text { yaf'alu } \\
\text { fä́ilan/maf'ülan } \\
\text { qadfáala }\end{array}$ & $\begin{array}{l}\text { fáala (auxiliary, perception) } \\
\text { sa-yaf'alu (perception) }\end{array}$ \\
\hline circumstantial clauses & $\begin{array}{l}\text { wa-huwa yaf'alu } \\
\text { wa-huwafä́ilun/maf'ülun } \\
\text { wa-qadfáala }\end{array}$ & \\
\hline
\end{tabular}


TABLE 8.2 The predicative paradigm across the board (cont.)

\begin{tabular}{|c|c|c|}
\hline & The predicative triad & Other verbal forms \\
\hline setting clauses & $\begin{array}{l}\text { baynā/baynamā huwa yaf'alu } \\
\text { baynā/baynamā huwa fā'ilun } \\
\text { * qad fa'ala not adjacent to } \\
\text { baynā/baynamā }\end{array}$ & \\
\hline presentative clauses & $\begin{array}{l}\text { ¿idā huwa yaf'alu } \\
\text { 'id̄ā huwa fāilun/maf'ūlun } \\
\text { 'id̄ā huwa qad fa'ala }\end{array}$ & \\
\hline
\end{tabular}

The identification of the predicative paradigm leads to some interesting observations with regard to the Classical Arabic verbal system in general. Firstly, by contrast to the general opinion (see above chapter 3), fa'cala and yaf'alu do not function as a binary pair. As a predicative form, fa'ala is quite marginal vis-àvis the dominant role played by yaf'alu and its counterparts, the participle and qad fa'ala. Secondly, despite their close syntactic mud̄ära'a 'resemblance' (see above 2.3.2), yaf'alu and the participle are distinct at several semantic levels, as presented in table 8.3 below:

TABLE 8.3 yaf'alu $v$ s. the participle

yaf'alu Participle

Grammatical aspect dynamic-progressive static

Verbal attribute habit / goal property / appointment

Transitivity (mostly) transitive intransitive

Lexical informativity higher lower

Thirdly, it is clear that qad fa'ala is not simply an extension of fa'ala, at both the syntactic and semantic levels: (a) qad fa'ala is far more frequent as a predicative, whereas fa'ala usually functions as the main verb; and (b) qad fa'ala indicates a temporally bounded situation, whereas fa'ala indicates a selfcontained event. These distinctions are summarized in table 8.4 below: 
TABLE 8.4 qad fa'ala $v s$. fa'ala

qadfáala fáala

Favored syntactic position predicative main

Grammatical aspect resultative perfective-eventive

Temporal reference coincidental self-contained 